\title{
Integration of inorganic micronutrients and natural starch based cationic flocculant in primary treated sewage effluent (PTSE) treatment
}

\author{
Wen Xing, Wenshan Guo, Huu-Hao Ngo ${ }^{*}$, Peter Cullum and Andrzej \\ Listowski \\ Faculty of Engineering and Information Technology, University of Technology, Sydney, \\ P.O. Box 123, Broadway, NSW 2007, Australia \\ * Correspondence author, tel: +61-2-9514-1693, fax: + 61-2-9514-2633, \\ E-mail: h.ngo@uts.edu.au
}

\begin{abstract}
In this study, a natural starch based cationic flocculant (SBCF) was firstly evaluated using a granular activated carbon fluidized-bed bioreactor (GAC-FBBR) to treat a high strength synthetic domestic wastewater (primary treated sewage effluent) containing refractory organic matters. The positive effect of SBCF on microorganisms and organic removal was obviously observed. When the optimal dose of SBCF (22 $\mathrm{mg} / \mathrm{L})$ combined with three major inorganic micronutrients $\left(\mathrm{CaCl}_{2}, \mathrm{MgSO}_{4}\right.$ and $\left.\mathrm{FeCl}_{3}\right)$ at different concentrations, the best modified dosages of $0.5 \mathrm{mg} / \mathrm{L}$ of $\mathrm{FeCl}_{3}, 5 \mathrm{mg} / \mathrm{L}$ of $\mathrm{MgSO}_{4}$ and $2 \mathrm{mg} / \mathrm{L} \mathrm{CaCl} 2$ could significantly improve the microbial activity and organic removal simultaneously.
\end{abstract}

Keywords: Trace nutrients, natural flocculant, microbial activity, refractory organic 
pollutants, wastewater treatment

\section{INTRODUCTION}

The flocculants used in the flocculation process for the water and wastewater treatment, can be classified into three groups: (i) inorganic flocculants (ii) organic synthetic polymer flocculants and (iii) naturally occurring bio-polymer flocculants (1). Inorganic flocculants are the most common flocculants used in water and wastewater treatment. Polymeric flocculants, synthetic as well as natural, because of their natural inertness to $\mathrm{pH}$ changes, low dosage, and easy handling, have become very popular in wastewater treatment (2). Although inorganic and organic synthetic polymer flocculants have been widely used due to their high flocculating efficiency and low cost, some of them are strong carcinogens and neurotoxic to humans. In addition, nonbiodegradable property presents another major drawback of polymeric flocculants, which will lead to "secondary pollution" for environment (3).

The natural based flocculants (NBFs) are environmental friendly and biodegradable, as well as present good flocculating ability. They can minimize environmental and health risks and have attracted more attention in water and wastewater treatment. The advantages of NBFs are (i) virtually toxic free; (ii) biodegradable in the environment; (iii) the raw products are often locally available, whereas industrialized flocculants may not be, and (iv) the sludge from flocculation may be reused $(4,5)$. The common NBFs can be processed from various sources of starches, such as potato, corn, cassava, 
arrowroot and yams. These starch based flocculants (SBFs) can be nonionic, cationic or anionic depending on the forms of processing and the substitutions. Since 1980s, some SBFs began to apply in water and wastewater treatment. The studies carried out by Campos et al. (6) proved that the addition of starch flocculants could enhance flocculation and sedimentation. Using $0.5 \mathrm{mg} / \mathrm{L}$ activated arrowroot starch, the alum dosage could be reduced by $20 \%$ and achieve better settled and filtered water qualities when compared with the use of alum alone. In addition, Dencs and Marton employed a starch based anionic flocculant (Greenfloc $®$ 213A) in water treatment. After flocculation of Greenfloc ${ }^{\circledR} 213 \mathrm{~A}$, approximately $87.5 \%$ of turbidity and $43.2 \%$ of COD were removed from raw water (7).

Biodegradability of flocculant is one of the most environmental important aspects of the environmental behavior as it cause less ecological problems in the long term than a persistent one while provides carbon source for the microbial activities. Xie et al. (3) indicated that the bacteria are capable of utilizing natural polysaccharide as a carbon source. In other words, the flocculant can be biodegraded by itself under the suitable conditions such as temperature, UV, moisture level, oxygen, nutrients, etc. Chang et al. (8) also evaluated the biodegradability of a copolymer of acrylamide and acryloyloxyethyltrimethylammonium chloride (AM/AETAC) by measuring biochemical oxygen demand (BOD) under aerobic conditions and performing a batch bioassay method (serum bottle test) for anaerobic environment. The results conclusively showed the AM/AETAC polymer was subject to partial hydrolysis and 
degradation. Singh et al. (2) investigated the biodegradability of polymers (grafted polysaccharides) by monitoring the viscosity decay, which presented they were very efficient, shear stable and biodegradable flocculants. They also exhibited turbulent drag reducing characteristics.

As NBFs can provide the carbon source for biodegradation, the additives are helpful for biomass growth and enhance the microbial activities in biological process for wastewater treatment. However, besides the carbon source, the trace nutrients such as magnesium, calcium, iron etc. are also very necessary and useful for metabolism of microorganisms. The trace nutrients limitation could deteriorate organic removal and affect the biofilm growth when running at a high organic loading rate (9). Gbolagade (10) reported that magnesium and calcium were the best macronutrients for the biomass production. In addition, Gobler and Sanudo-Wilhelmy (11) found the iron also enhanced some of bacterial growth at suitable concentrations.

Thus, the main aims of this study are: (i) to evaluate the effect of trace nutrients on the biodegradability of a natural starch based cationic flocculant (SBCF) by viscosity decay, (ii) to investigate the microbial activity in a granular activated carbon fluidized bed bioreactor (GAC-FBBR) with SBCF addition, and (iii) to find out the optimal concentrations of inorganic micronutrients $(\mathrm{Fe}, \mathrm{Ca}$ and $\mathrm{Mg}$ ) when combining with SBCF as a new flocculant. 


\section{MATERIALS AND METHODS}

\section{Synthetic wastewater}

The experiments were conducted using a synthetic wastewater to avoid any fluctuation in the feed concentration and provide a continuous source of biodegradable organic pollutants together with refractory organics such as humic acid, tannic acid, lignin, polysaccharide and other high molecular carbohydrates (Table 1). The synthetic wastewater originally contained some trace nutrients, which was used to simulate primary treated sewage effluent (PTSE) (just after primary treatment process). The average concentration of dissolved organic carbon (DOC), chemical oxygen demand (COD), ammonium-nitrogen $\left(\mathrm{NH}_{4}-\mathrm{N}\right)$ and orthophosphate $\left(\mathrm{PO}_{4}-\mathrm{P}\right)$ contained in PTSE were 120, 300, 15 and $3.3 \mathrm{mg} / \mathrm{L}$, respectively (COD:N:P=100:5:1).

Table 1. Constituents of synthetic PTSE

\section{Natural starch based cationic flocculant (SBCF) and GAC used}

SBCF provided by HYDRA 2002 Research, Development and Consulting Ltd., Hungary was selected as a representative SBF in this study. The major components of this flocculant are cationic starch ether and water. It is completely soluble in water with a density of $1050 \mathrm{~kg} / \mathrm{m}^{3}$. The coal based granular activated carbon (GAC) (ACTICARB GS1300, Activated Carbon Technologies Pty Ltd, Australia) was used in this study. The surface area, iodine number, maximum ash and moisture contents are $>1100 \mathrm{BET} \mathrm{m}^{2} / \mathrm{g},>1100 \mathrm{mg} /$ (g.min), $10 \%$ and $3 \%$, respectively. The GAC was rinsed with distilled water to remove fines and dried at $105^{\circ} \mathrm{C}$ in the oven prior to the 
experiments.

\section{Biodegradation study of SBCF}

1\% SBCF solution (dissolved in distilled water) was used for this study and the biodegradability of SBCF was evaluated by monitoring the viscosity decay using a falling ball type viscosity meter (Gilmont ${ }^{\circledR}$ Instruments) with the range of $0.2-10$ mPa.s. Viscosity measurement was conducted at the room temperature of $25^{\circ} \mathrm{C}$. To evaluate the effect of nutrients on the SBCF biodegradation, $\left(\mathrm{NH}_{4}\right)_{2} \mathrm{SO}_{4}$ as nitrogen, $\mathrm{KH}_{2} \mathrm{PO}_{4}$ as phosphorus, and trace nutrients $\left(\mathrm{MgSO}_{4}, \mathrm{CaCl}_{2}\right.$ and $\left.\mathrm{FeCl}_{3}\right)$ were added into SBCF solution. The $\mathrm{pH}$ of solution was maintained at 7.

\section{Effect of SBCF on microbial activity}

The effect of SBCF on microbial activity was investigated by comparing GAC inoculation (75 mL of GAC) in three fluidized bed bioreactors (FBBRs) with $100 \%$ recirculation for 15 days. A volume of 10 L/day PTSE was fed into each FBBR at a feeding rate of $180 \mathrm{~mL} / \mathrm{min}$. Three GAC-FBBRs were operated simultaneously at an actual depth of $240 \mathrm{~mm}$ with bed expansion of $60 \mathrm{~mm}$. One of the GAC-FBBRs was a parallel control system without SBCF addition, while 11mg/L SBCF (containing $5 \mathrm{mg} / \mathrm{L} \mathrm{TC}$ ) and $22 \mathrm{mg} / \mathrm{L} \mathrm{SBCF}$ (containing $10 \mathrm{mg} / \mathrm{L} \mathrm{TC}$ ) were added in the other two GAC-FBBRs every day, respectively. The biomass attached on GAC, oxygen uptake rate (OUR) and DOC were monitored. 


\section{Optimizing the concentrations of inorganic micronutrients}

Besides the organic carbon, trace nutrients such as calcium, magnesium, iron are also very important for biomass growth. Thus, SBCF was combined with the three major trace nutrients in different concentrations, and jar tests was conducted using GAC as attached growth media (25g/L GAC) for 20 days. The mixtures of SBCF and inorganic nutrients as bioflocculant were added to $1 \mathrm{~L}$ beakers to treat PTSE. Certain amount of GAC was taken out periodically for analyses. The microbial activities were investigated in terms of biomass growth, and OUR.

\section{Analysis}

DOC was measured using the Analytikjena Multi N/C 2000. The analysis of biomass (monitored as mixed liquor volatile suspended solids, MLVSS) was according to Standard Methods (12). For measuring MLVSS, two samples were taken each time and the average value was then calculated. YSI 5300 Biological Oxygen Monitor was used to measure oxygen uptake rate (OUR) due to its usefulness in measuring samples including respiration, oxidative activity, and cellular metabolism studies.

\section{RESULTS AND DISCUSSION}

\section{Biodegradability of SBCF}

There are many factors affect the biodegradability of SBCF such as temperature, moisture level, oxygen, UV etc. (2). To eliminate the influence of these factors, the temperature, moisture, oxygen and UV were controlled in the common room 
conditions. Since all of the solutions were prepared using distilled water, the decay of relative viscosity $\eta_{\text {rel }}$ (ratio of the testing solution's viscosity to pure distilled water's viscosity) was used to examine the biodegradability of SBCF and the results were shown in Fig. 1. As can be seen, the biodegradation has been observed for all the SBCF solutions with and without nutrients addition. The relative viscosity of SBCF solution decreased from 4.35 to 2.98 at the first 6 days and reached to stable stage afterwards. However, faster biodegradation was found in the cases of SBCF solution with the $\mathrm{N}$ and $\mathrm{P}$ addition $\left(\eta_{\text {rel }}\right.$ decrease of 1.63), and SBCF solution with $\mathrm{N}, \mathrm{P}$ and trace nutrients $\left(\eta_{\text {rel }}\right.$ decrease of 1.66). It indicated that as starch based flocculant, SBCF is biodegradable and the nutrients addition could enhance SBCF biodegradation.

Figure 1. Relative viscosity versus time to study the biodegradation of SBCF with and without nutrients addition (Temperature $=25^{\circ} \mathrm{C}$ )

\section{Effect of SBCF on microbial activity}

Fig. 2 and Table 2 showed the biomass attached on GAC and OURs of biomass in three GAC-FBBRs with and without SBCF addition. The biomass attached on GAC in FBBR with $22 \mathrm{mg} / \mathrm{L} \mathrm{SBCF}$ addition elucidated the fastest increase (up to $5.75 \mathrm{~g} / \mathrm{L}$ ) within operation period, while the control FBBR and FBBR with 11mg/L SBCF addition had 3.1g/L and $4.05 \mathrm{~g} / \mathrm{L}$ biomass growth respectively. The OUR can be used as an indicator for microbial activity on GAC at different period of acclimatization, as it presents the dissolved oxygen (DO) consumption rate of biomass on the GAC. The OUR of biomass on the GAC in FBBR with $22 \mathrm{mg} / \mathrm{L}$ SBCF also had better 
performance and could reach equilibrium faster than others. Both of the biomass and OUR results showed that there were the most microbial substances on the GAC in FBBR with $22 \mathrm{mg} / \mathrm{L}$ SBCF addition. Hence, the higher dosage of SBCF, the higher biomass growth could be observed in FBBR.

Table 2. Comparison of OUR variation of biomass attached on GAC with and without SBCF addition

Figure 2. Biomass growth on GAC in three GAC-FBBRs with and without SBCF addition

The DOC removal efficiencies of three GAC-FBBRs with and without SBCF addition were illustrated in Fig. 3. DOC removal efficiencies of all the FBBRs kept increasing until 10th day when the biomass growth on GAC started to reach steady phase. Compared with other GAC-FBBRs, the GAC-FBBR with $22 \mathrm{mg} / \mathrm{L}$ SBCF addition had much better performance, resulting in the highest DOC removal of $66 \%$ while only $49 \%$ and $55 \%$ of DOCs were removed by control GAC-FBBR and the one with $11 \mathrm{mg} / \mathrm{L} \mathrm{SBCF}$ addition. Under the same operating conditions, the performance of GAC-FBBR was dependent on the number of microorganisms attached onto the GAC for organic biodegradation. Thus, the DOC removal efficiency also revealed that the SBCF could provide carbon source for the biomass growth and be very helpful for microbial activities as a biodegradable flocculant.

Figure 3. DOC removal efficiencies of three GAC-FBBRs with and without SBCF addition (average initial DOC $=120 \mathrm{mg} / \mathrm{L}$ )

\section{The effect of inorganic micronutrients on SBCF performance}

Combined SBCF with individual inorganic trace nutrient 
The combinations of SBCF (22 mg/L) with two individual inorganic trace nutrients $\left(\mathrm{CaCl}_{2}\right.$, and $\left.\mathrm{MgSO}_{4}\right)$ were evaluated by comparing the microbial activity of biomass growth on GAC. GAC was acclimatized for 20 days through the jar tests. When the concentrations of $\mathrm{CaCl}_{2}$ varied from 2 to $10 \mathrm{mg} / \mathrm{L}, 2 \mathrm{mg} / \mathrm{L}$ and $5 \mathrm{mg} / \mathrm{L}$ concentrations resulted in the higher biomass growth, which led to biomass of $2.95 \mathrm{mg} / \mathrm{L}, 2.9 \mathrm{mg} / \mathrm{L}$ respectively (Fig. 4.). The results also indicated that $\mathrm{CaCl}_{2}$ was helpful for biomass growth. For all the cases, significant growth of biomass was observed in the first 10 days. Similarly, the better OUR values were obtained with 2 and $5 \mathrm{mg} / \mathrm{L} \mathrm{CaCl} 2$ addition (1.89 and $1.69 \mathrm{mgO}_{2} / \mathrm{L} . \mathrm{h}$ respectively) (Table 3). However, with $10 \mathrm{mg} / \mathrm{L}$ of $\mathrm{CaCl}_{2}$, the OURs dropped more than 2 times $\left(0.79 \mathrm{mgO}_{2} / \mathrm{L} . \mathrm{h}\right)$ indicating over dose of the nutrient. Hotchkiss (13) has also reported that the bi-valent salts were more toxic than the monovalent salts. High concentration of calcium was toxic and could inhibit to the growth of bacteria. Although 2 and $5 \mathrm{mg} / \mathrm{L} \mathrm{CaCl}_{2}$ addition did not presented much difference on the biomass growth, the $2 \mathrm{mg} / \mathrm{L} \mathrm{CaCl}{ }_{2}$ always exhibited the strongest micro-activity of the microorganisms attached on GAC which was correspondent to the highest DO consumption rate within 30 mins. Thus, $2 \mathrm{mg} / \mathrm{L}$ $\mathrm{CaCl}_{2}$ was selected as the favorable concentration for combination with SBCF.

Figure 4. Biomass attached on GAC for $22 \mathrm{mg} / \mathrm{L}$ of SBCF combined with different concentrations of $\mathrm{CaCl}_{2}$

Table 3. Comparison of OUR values for SBCF combined with different concentrations of $\mathrm{CaCl}_{2}$

The evaluation of combined SBCF and different concentrations of $\mathrm{MgSO}_{4}$ for $\mathrm{GAC}$ acclimatization was also performed (Table 4 and Fig. 5.). The combined flocculant 
using $22 \mathrm{mg} / \mathrm{L} \mathrm{SBCF}$ and $2 \mathrm{mg} / \mathrm{L} \mathrm{MgSO}_{4}$ gained the lowest biomass growth $(2.55$ $\mathrm{g} / \mathrm{L}$ ), whereas both of biomass attached on the GAC for addition of $22 \mathrm{mg} / \mathrm{L} \mathrm{SBCF}$ combined with $5 \mathrm{mg} / \mathrm{L}$ and $10 \mathrm{mg} / \mathrm{L}^{\mathrm{MgSO}_{4}}$ achieved to the steady phase and was around $3.1 \mathrm{~g} / \mathrm{L}$ after 15 days operation. OURs indicated the stronger microbial activity when employed $\mathrm{MgSO}_{4}$ concentrations of 5 and $10 \mathrm{mg} / \mathrm{L}\left(1.89\right.$ and $1.83 \mathrm{mgO}_{2} / \mathrm{L} . \mathrm{h}$ respectively). Thus, 5 and $10 \mathrm{mg} / \mathrm{L}$ were selected for conducting next-step experiment. Table 4. Comparison of OUR variation for SBCF combined with different concentrations of $\mathrm{MgSO}_{4}$

Figure 5. Biomass attached on GAC for $22 \mathrm{mg} / \mathrm{L}$ of SBCF combined with different concentrations of $\mathrm{MgSO}_{4}$

\section{Combination of $\mathrm{SBCF}$ together with $\mathrm{FeCl}_{3}, \mathrm{CaCl}_{2}$ and $\mathrm{MgSO}_{4}$}

According to the optimum concentrations of SBCF (22 mg/L), $\mathrm{CaCl}_{2}(2 \mathrm{mg} / \mathrm{L})$ and $\mathrm{MgSO}_{4}(5$ and $10 \mathrm{mg} / \mathrm{L}), \mathrm{FeCl}_{3}$ was varied at three different concentrations of $0.5,1$ and $2 \mathrm{mg} / \mathrm{L}$. The combinations of different compounds were shown in Table 5. The biomass attached on GAC and OURs were measured and the results were shown in Fig. 6. and Table 6. As can be seen from the figure, the lowest dose of $\mathrm{FeCl}_{3}(0.5$ $\mathrm{mg} / \mathrm{L})$ illustrated the highest number of biomass yield $(3.55 \mathrm{mg} / \mathrm{L}$ for Flocculant A and $3.5 \mathrm{mg} / \mathrm{L}$ for Flocculant D). On the contrary, the high dose of $\mathrm{FeCl}_{3}$ led to decline of the biomass growth while the decrease values of OUR also confirmed that the negative effect of high $\mathrm{FeCl}_{3}$ concentration on bioactivity. For instance, the OURs of Flocculant $\mathrm{C}$ and $\mathrm{F}$ dropped significantly from 8.74 to $3.43 \mathrm{mgO}_{2} / \mathrm{L}$.h and from 11.54 to $4.07 \mathrm{mgO}_{2} / \mathrm{L} . h$, respectively. The result was similar to the previous research about the influence of $\mathrm{FeCl}_{3}$ concentrations on the microorganism growth (11). In addition, 5 
and $10 \mathrm{mg} / \mathrm{L} \mathrm{MgSO}_{4}$ exhibited similar biomass growth on GAC and OURs when different doses of $\mathrm{FeCl}_{3}$ were varied. Based on the economical point of view, the 5 $\mathrm{mg} / \mathrm{L}$ was chosen to be the optimal $\mathrm{MgSO}_{4}$ concentration for the combined flocculant. Fig. 7. showed the DOC removal efficiency of different combined flocculants. Similar to the biomass and OURs observed, Flocculant $A$ and D resulted in $71.8 \pm 13.4 \%$ and $70.6 \pm 13.1 \%$ organic removal form PTSE. Meanwhile, the worst DOC removals were obtained when applying Flocculant $\mathrm{C}$ and $\mathrm{F}(63.1 \pm 8 \%$ and $60.7 \pm 9 \%$ respectively). Thus, compared with other combined flocculants, Flocculant A (22 mg/L SBCF + 0.5 $\mathrm{mg} / \mathrm{L} \mathrm{FeCl}_{3}+5 \mathrm{mg} / \mathrm{L} \mathrm{MgSO}_{4}+2 \mathrm{mg} / \mathrm{L} \mathrm{CaCl}_{2}$ ) is considered as the most effective flocculant and will be applied for the further studies.

Table 5. The combined conditions of inorganic trace nutrients with SBCF

Figure 6. Biomass attached on GAC with different combinations of flocculants on $15^{\text {th }}$ day ( $\mathrm{SBCF}$ of $22 \mathrm{mg} / \mathrm{L}$ and $\mathrm{CaCl}_{2}$ of $2 \mathrm{mg} / \mathrm{L}$ for all conditions; $\mathrm{MgSO}_{4}$ of $5 \mathrm{mg} / \mathrm{L}$ for $\mathrm{A}, \mathrm{B}, \mathrm{C}$ and $10 \mathrm{mg} / \mathrm{L}$ for D, E, F; $\mathrm{FeCl}_{3}$ of $0.5 \mathrm{mg} / \mathrm{L}$ for $\mathrm{A}, \mathrm{D} ; 1 \mathrm{mg} / \mathrm{L}$ for B, E; 2 $\mathrm{mg} / \mathrm{L}$ for $\mathrm{C}, \mathrm{F}$ )

Table 6. Comparison of OUR variation with different combined flocculants

Figure 7. DOC removal efficiency of the different combined flocculants (initial DOC $=120 \mathrm{mg} / \mathrm{L})\left(\mathrm{SBCF}\right.$ of $22 \mathrm{mg} / \mathrm{L}$ and $\mathrm{CaCl}_{2}$ of $2 \mathrm{mg} / \mathrm{L}$ for all conditions; $\mathrm{MgSO}_{4}$ of 5 $\mathrm{mg} / \mathrm{L}$ for $\mathrm{A}, \mathrm{B}, \mathrm{C}$ and $10 \mathrm{mg} / \mathrm{L}$ for D, E, F; $\mathrm{FeCl}_{3}$ of $0.5 \mathrm{mg} / \mathrm{L}$ for $\mathrm{A}, \mathrm{D} ; 1 \mathrm{mg} / \mathrm{L}$ for B, $\mathrm{E} ; 2 \mathrm{mg} / \mathrm{L}$ for $\mathrm{C}, \mathrm{F}$ )

\section{CONCLUSIONS}

The study investigated the performance of a SBCF for treating a synthetic PTSE containing refractory organic pollutants. Several important inorganic trace nutrients $\left(\mathrm{CaCl}_{2}, \mathrm{MgSO}_{4}\right.$ and $\left.\mathrm{FeCl}_{3}\right)$ were selected to modify the SBCF in order to improve the organic removal and enhance the bio-activity of microorganisms attached on GAC. 
The outcomes can be summarized as follows:

- SBCF showed a very good biodegradability by viscosity decay and the inorganic nutrients addition could enhance SBCF biodegradation. However, higher concentration of $\mathrm{FeCl}_{3}$ resulted in inhibition of biomass growth.

- As a biodegradable flocculant, SBCF could provide carbon source for the biomass growth and enhance the organic removal in GAC-FBBRs. $22 \mathrm{mg} / \mathrm{L}$ SBCF addition led to almost double amount of biomass on GAC in FBBR than that without SBCF addition.

- The modified flocculant containing $22 \mathrm{mg} / \mathrm{L}$ of SBCF, $0.5 \mathrm{mg} / \mathrm{L}$ of $\mathrm{FeCl}_{3}, 5$ $\mathrm{mg} / \mathrm{L}$ of $\mathrm{MgSO}_{4}$ and $2 \mathrm{mg} / \mathrm{L} \mathrm{CaCl}_{2}$ was evaluated through the batch tests and considered as a better flocculant used in future study.

\section{ACKNOWLEDGEMENTS}

This research was funded by ARC linkage project (LP 0775149). The authors are grateful to the support of Sydney Olympic Park Authority (SOPA), Activated Carbon Technologies Pty Ltd, UTS Chancellor's Postdoctoral Research Fellowship and UTS

Early Career Researcher Grants. The authors also thank HYDRA 2002 Research, Development and Consulting Ltd., Hungary for providing the starch based cationic flocculant.

\section{REFERENCES}

1. Shih, I.L., Van, Y.T., Yeh, L.C., Lin, H.G., Chang, Y.N. (2001) Production of a 
biopolymer flocculant from Bacillus licheniformis and its flocculation properties. Bioresource Technology, 78: 267-272.

2. Singh, R.P., Karnakar, G.P., Rath, S.K., Karmakar, N.C., Pandey, S.R., Tripathy, T., Panda, J., Kanan, K., Jain, S.K., Lan, N.T. (2000) Biodegradable drag reducing agents and flocculants based on polysaccharides: material and application. Polymer Engineering and Science, 40: 46-60.

3. Xie, C.X., Feng, Y.J., Cao, W.P., Xia, Y., Lu, Z.Y. (2007) Novel biodegradable flocculating agents prepared by phosphate modification of Konjac. Carbohydrate Polymers, 67: 566-571.

4. Bratby, J. (2006) Coagulation and flocculation in water and wastewater treatment.2nd Ed.; IWA Publishing: London, UK.

5. Rizzo, L., Lofrano, G., Grassi, M., Belgiorno, V. (2008) Pre-treatment of olive mill wastewater by chitosan coagulation and advanced oxidation process. Separation and Purification Technology, 63(3): 648-653.

6. Campos J.R., Vieira M.B.S., Campos L.V. (1984) Use of starch derived from arrowroot gelatinized with sodium hydroxide as flocculant in potable water treatment (in Portuguese). Revista DAE, 44, 136, Brazil.

7. Dence, J., Marton, G..(1998) Application of starch based anionic flocculant in the water treatment. 10th European Conference Technology Exhibition, Wurzburg.

8. Chang, L.L., Raudenbush, D.L., Dentel, S.K. (2001) Aerobic and anaerobic biodegradability of a flocculent polymer. Water Science and Technology, 44 (2- 
3): 461-468.

9. Cresson, R., Carrere, H., Delgenes, J. P., Bernet, N. (2006) Biofilm formation during the start-up period of an anaerobic biofilm reactor- impact of nutrient complementation. Biochemical Engineering Journal, 30: 55-62.

10. Gbolagade, J.S. (2006) The effect of different nutrient sources on biomass production of lepiota procera in submerged liquid cultures. African Journal of Biotechnology, 5(12): 1246-1249.

11. Gobler, C.J., Sanudo-Wilhelmy, S.A. (2001) Effect of organic carbon, organic nitrogen, inorganic nutrients, and iron additions on the growth of phytoplankton and bacterial during a brown tide bloom. Marine Ecology Process Series, 209: $19-34$.

12. APHA. (1998) Standard Methods for the Examination of Water and Wastewater, 20th Ed.; American Public Health Association: Washington, DC.

13. Hotchkiss, M. (1923) Studies on Salt Action VI. The Stimulating and Inhibitive Effect of Certain Cations upon Bacterial Growth. Journal Bacteriology, 8(2): $141-162$. 
Table 1. Composition of synthetic PTSE

\begin{tabular}{ll}
\hline Compound & Concentration $(\mathrm{mg} / \mathrm{L})$ \\
\hline \hline Glucose & 230 \\
$\left(\mathrm{NH}_{4}\right)_{2} \mathrm{SO}_{4}$ & 71 \\
$\mathrm{KH}_{2} \mathrm{PO}_{4}$ & 13.2 \\
Peptone & 2.7 \\
Humic acid & 4.2 \\
Tannic acid & 4.2 \\
(Sodium) lignin sulfonate & 2.4 \\
Sodium lauryle sulphate & 0.94 \\
Acacia gum powder & 4.7 \\
Arabic acid (polysaccharide) & 5 \\
& \\
$\mathrm{Trace}$ nutrient & \\
$\mathrm{MgSO}_{4} \cdot 7 \mathrm{H}_{2} \mathrm{O}$ & 5.07 \\
$\mathrm{CaCl}_{2} \cdot 2 \mathrm{H}_{2} \mathrm{O}$ & 0.368 \\
$\mathrm{MnCl}_{2} \cdot 4 \mathrm{H}_{2} \mathrm{O}$ & 0.275 \\
$\mathrm{ZnSO}_{4} \cdot 7 \mathrm{H}_{2} \mathrm{O}$ & 0.44 \\
$\mathrm{FeCl}_{3}$ & 1.45 \\
$\mathrm{CuSO}_{4} \cdot 5 \mathrm{H}_{2} \mathrm{O}$ & 0.391 \\
$\mathrm{CoCl}_{2} \cdot 6 \mathrm{H}_{2} \mathrm{O}$ & 0.42 \\
$\mathrm{Na}_{2} \mathrm{MoO}_{4} \cdot 2 \mathrm{H}$ & 1.26 \\
$\mathrm{Yeast} \mathrm{extract}$ & 20 \\
\hline
\end{tabular}


Table 2. Comparison of OUR variation of biomass attached on GAC with and without SBCF addition

\begin{tabular}{cccc}
\hline \multirow{2}{*}{ Day } & \multicolumn{3}{c}{ OUR $\left(\mathrm{mgO}_{2} / \mathrm{L} . \mathrm{h}\right)$} \\
\cline { 2 - 4 } & $\begin{array}{c}\text { without SBCF } \\
\text { addition }\end{array}$ & $\begin{array}{c}\text { with } 11 \mathrm{mg} / \mathrm{L} \mathrm{SBCF} \\
\text { addition }\end{array}$ & $\begin{array}{c}\text { with } 22 \mathrm{mg} / \mathrm{L} \mathrm{SBCF} \\
\text { addition }\end{array}$ \\
\hline 1 & 10.87 & 6.96 & 11.34 \\
5 & 12.49 & 13.38 & 16.63 \\
10 & 8.64 & 12.27 & 15.65 \\
15 & 10.66 & 12.07 & 16.44 \\
\hline
\end{tabular}


Table 3. Comparison of OUR values for SBCF combined with different concentrations of $\mathrm{CaCl}_{2}$

\begin{tabular}{ccccc}
\hline & \multicolumn{4}{c}{ OUR $\left(\mathrm{mg} \mathrm{O}_{2} / \mathrm{L} . \mathrm{h}\right)$} \\
\cline { 2 - 5 } Day & $\begin{array}{c}22 \mathrm{mg} / \mathrm{L} \\
\mathrm{SBCF}\end{array}$ & $\begin{array}{c}22 \mathrm{mg} / \mathrm{L} \mathrm{SBCF} \\
+\end{array}$ & $\begin{array}{c}22 \mathrm{mg} / \mathrm{L} \mathrm{SBCF} \\
+\end{array}$ & $\begin{array}{c}22 \mathrm{mg} / \mathrm{LSBCF} \\
+\end{array}$ \\
& 0.54 & 0.64 & 0.88 & 0.59 \\
5 & 0.76 & 1.15 & 1.13 & 0.96 \\
7 & 0.71 & 1.40 & 1.21 & 0.88 \\
10 & 0.95 & 1.98 & 1.40 & 0.99 \\
12 & 0.88 & 1.89 & 1.69 & 0.79 \\
15 & & & & $\mathrm{CaCl}_{2}$ \\
\hline
\end{tabular}


Table 4. Comparison of OUR variation for SBCF combined with different concentrations of $\mathrm{MgSO}_{4}$

\begin{tabular}{|c|c|c|c|c|}
\hline \multirow{2}{*}{ Day } & \multicolumn{4}{|c|}{$\mathrm{OUR}^{\left(\mathrm{mgO}_{2} / \mathrm{L} . \mathrm{h}\right)}$} \\
\cline { 2 - 5 } & $\begin{array}{c}22 \mathrm{mg} / \mathrm{L} \\
\mathrm{SBCF}\end{array}$ & $\begin{array}{c}22 \mathrm{mg} / \mathrm{L} \mathrm{SBCF} \\
+\end{array}$ & $\begin{array}{c}22 \mathrm{mg} / \mathrm{L} \mathrm{SBCF} \\
+\end{array}$ & $\begin{array}{c}22 \mathrm{mg} / \mathrm{LSBCF} \\
+ \\
+\end{array}$ \\
\hline 5 & 0.54 & 0.78 & 1.28 & 1.64 \\
\hline 7 & 0.76 & 0.96 & 1.28 & 2.04 \\
\hline 10 & 0.71 & 1.28 & 1.50 & 2.10 \\
\hline 12 & 0.95 & 1.22 & 1.81 & 1.69 \\
\hline 15 & 0.88 & 0.95 & 1.89 & 1.83 \\
\hline
\end{tabular}


Table 5. The combined conditions of inorganic trace nutrients with SBCF

\begin{tabular}{|c|c|c|c|c|}
\hline Flocculant ID & $\mathrm{SBCF}(\mathrm{mg} / \mathrm{L})$ & $\mathrm{FeCl}_{3}(\mathrm{mg} / \mathrm{L})$ & $\mathrm{MgSO}_{4}(\mathrm{mg} / \mathrm{L})$ & $\mathrm{CaCl}_{2}(\mathrm{mg} / \mathrm{L})$ \\
\hline $\mathrm{A}$ & 22 & 0.5 & 5 & 2 \\
\hline B & 22 & 1 & 5 & 2 \\
\hline C & 22 & 2 & 5 & 2 \\
\hline D & 22 & 0.5 & 10 & 2 \\
\hline E & 22 & 1 & 10 & 2 \\
\hline F & 22 & 2 & 10 & 2 \\
\hline
\end{tabular}


Table 6. Comparison of OUR variation with different combined flocculants

\begin{tabular}{|c|c|c|c|c|c|c|}
\hline \multirow{2}{*}{ Day } & \multicolumn{7}{|c|}{ OUR $\left(\mathrm{mgO}_{2} / \mathrm{L} . \mathrm{h}\right)$} \\
\cline { 2 - 7 } & $\mathrm{A}$ & $\mathrm{B}$ & $\mathrm{C}$ & $\mathrm{D}$ & $\mathrm{E}$ & $\mathrm{F}$ \\
\hline 3 & 1.72 & 1.32 & 1.25 & 1.49 & 1.39 & 0.63 \\
\hline 5 & 9.62 & 3.58 & 5.26 & 9.75 & 4.29 & 1.01 \\
\hline 7 & 11.29 & 4.78 & 4.44 & 11.20 & 8.37 & 5.92 \\
\hline 10 & 14.03 & 7.84 & 6.56 & 12.08 & 4.58 & 3.65 \\
\hline 12 & 15.77 & 10.73 & 6.42 & 15.18 & 10.61 & 6.83 \\
\hline 15 & 8.74 & 5.42 & 3.43 & 11.54 & 6.12 & 4.07 \\
\hline
\end{tabular}




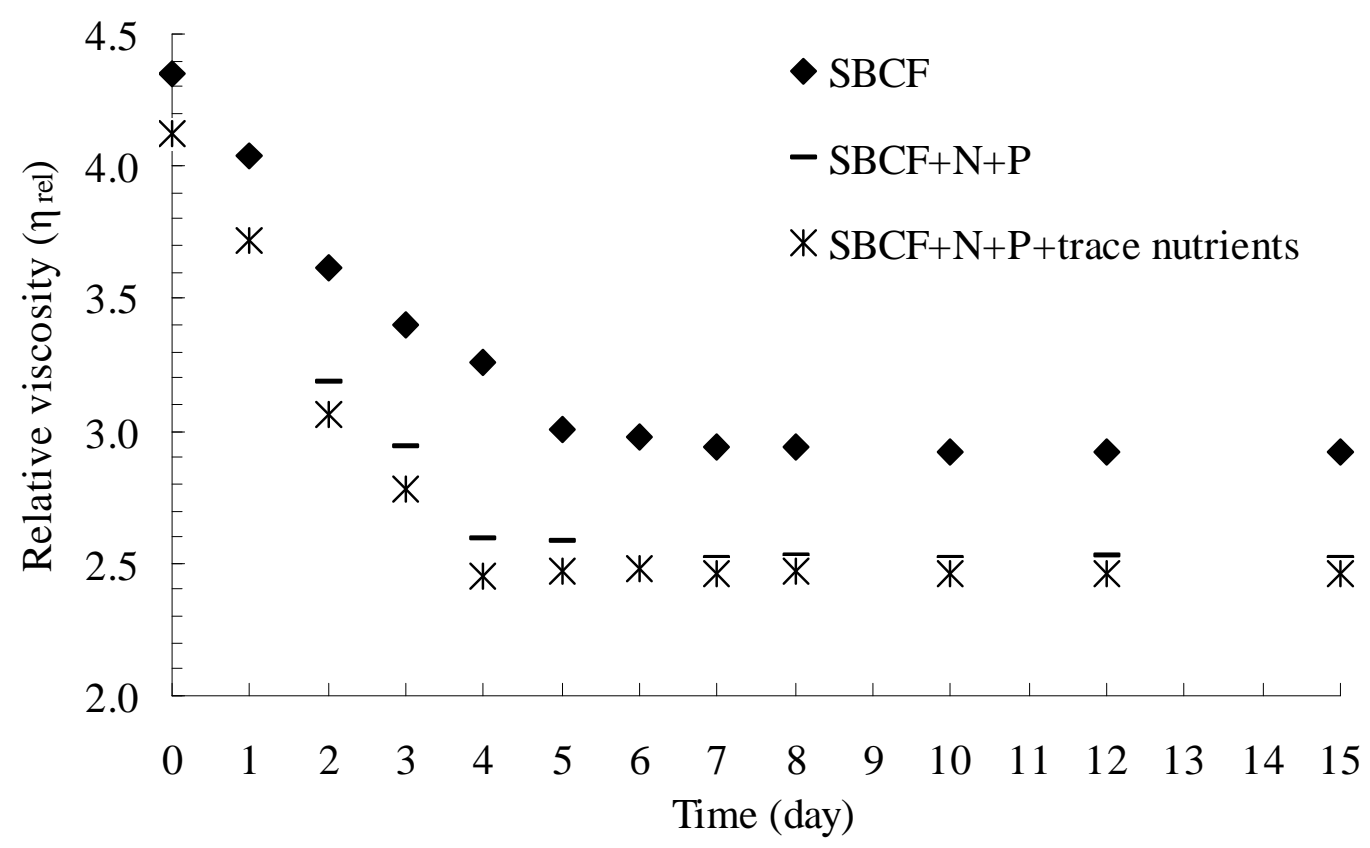

Figure 1. Relative viscosity versus time to study the biodegradation of SBCF with and without nutrients addition (Temperature $=25^{\circ} \mathrm{C}$ ) 


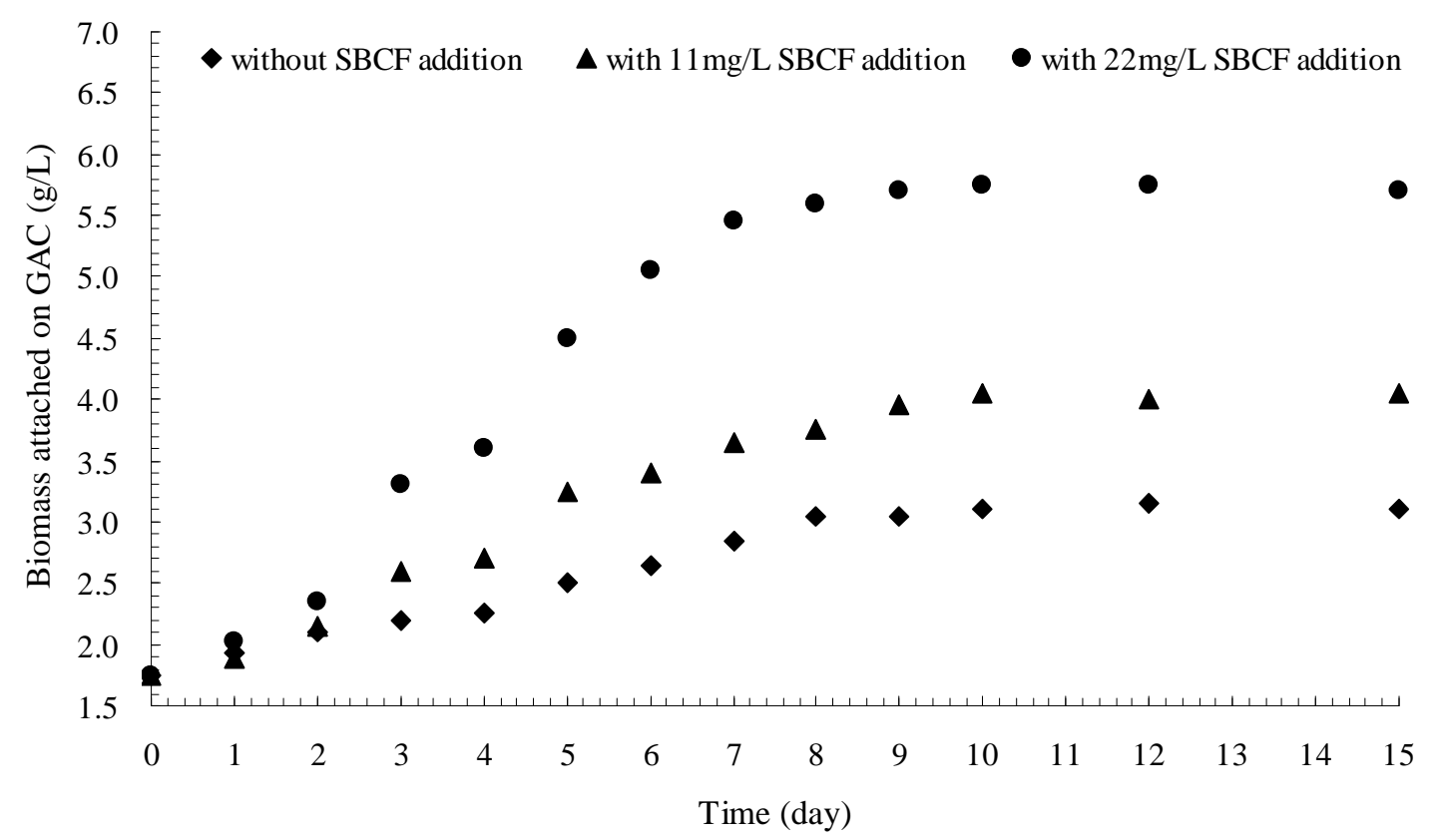

Figure 2. Biomass growth on GAC in three GAC-FBBRs with and without SBCF addition 


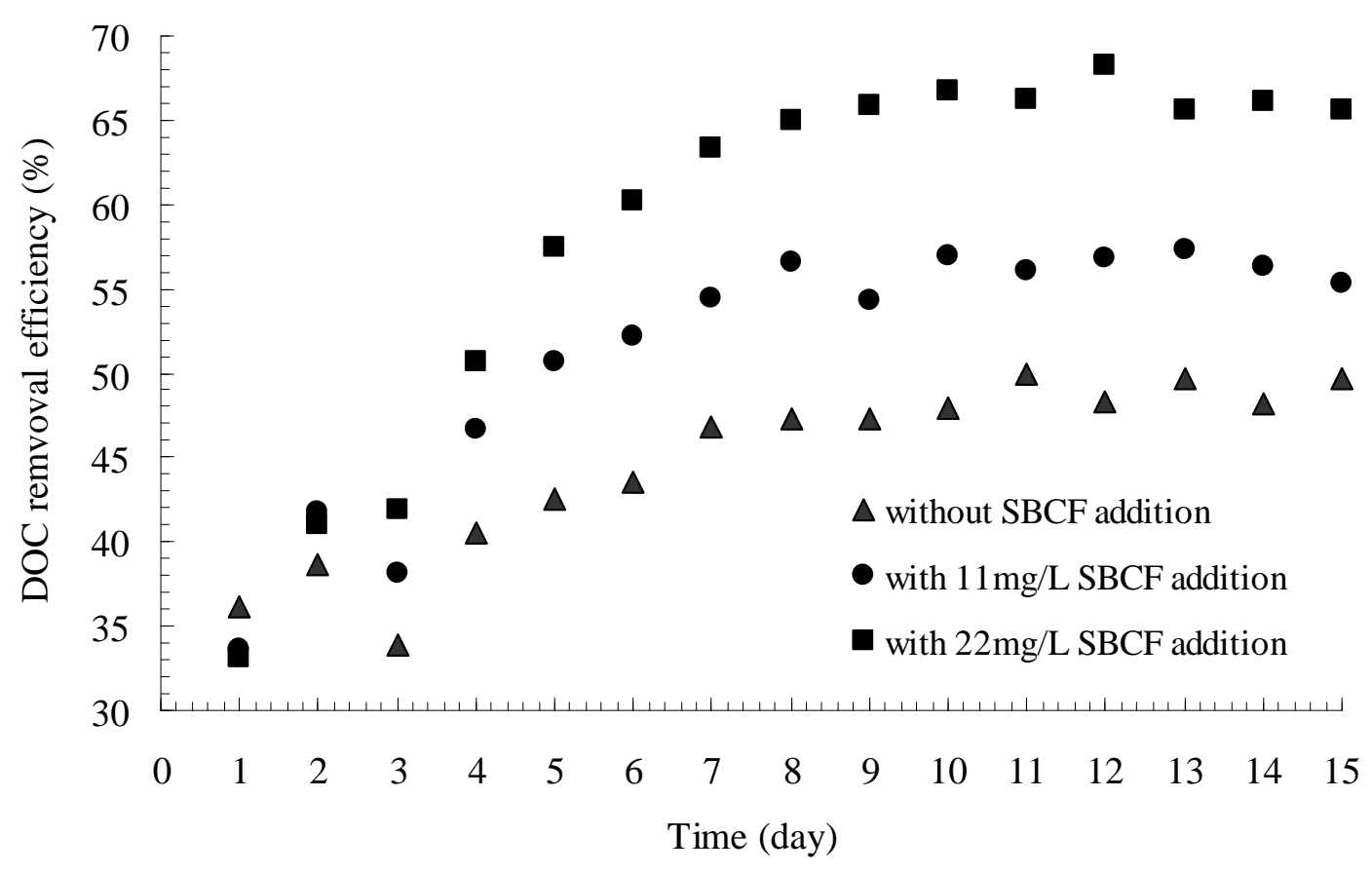

Figure 3. DOC removal efficiencies of three GAC-FBBRs with and without SBCF addition (average initial DOC $=120 \mathrm{mg} / \mathrm{L}$ ) 


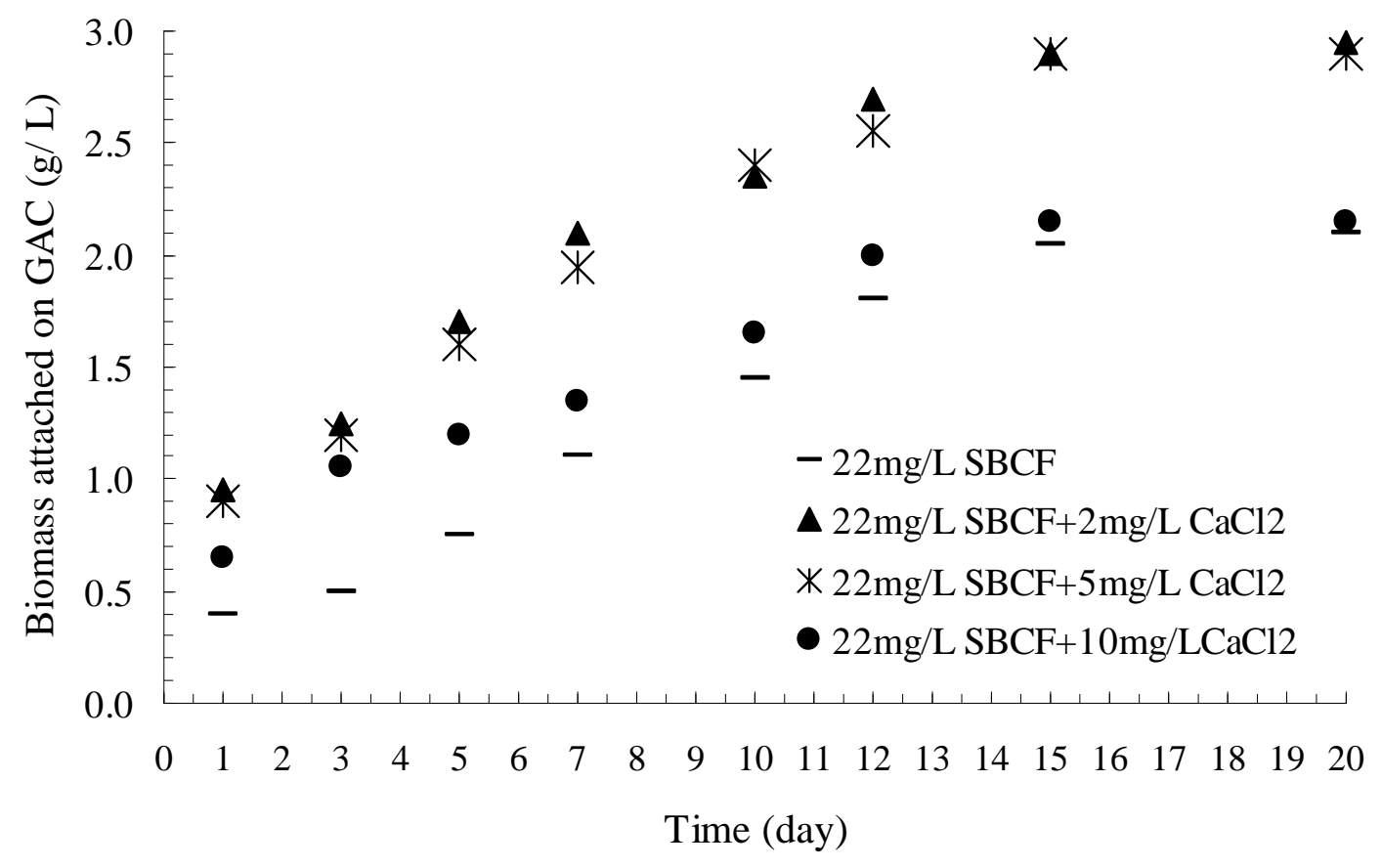

Figure 4. Biomass attached on GAC for $22 \mathrm{mg} / \mathrm{L}$ of SBCF combined with different concentrations of $\mathrm{CaCl}_{2}$ 


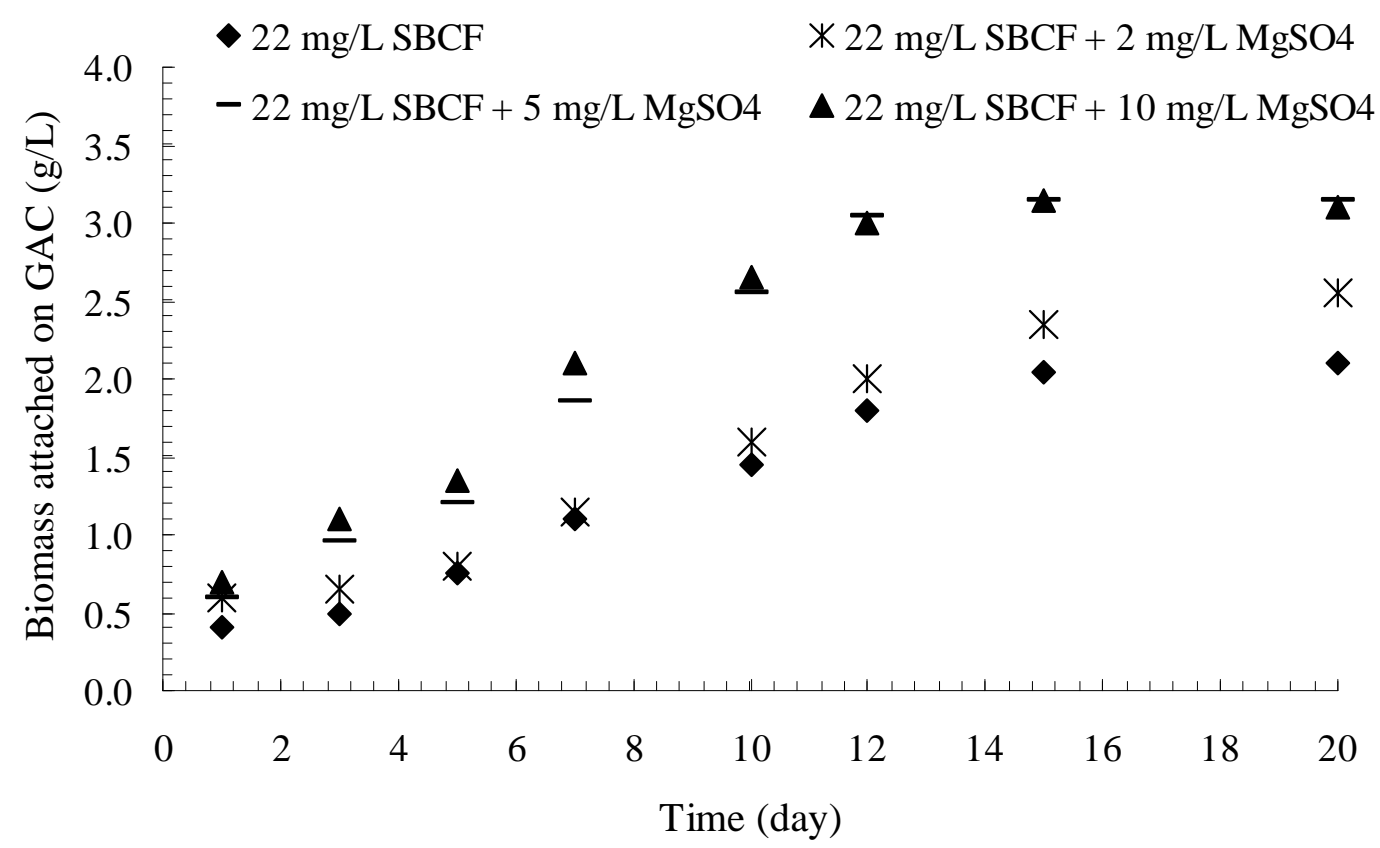

Figure 5. Biomass attached on GAC for $22 \mathrm{mg} / \mathrm{L}$ of SBCF combined with different concentrations of $\mathrm{MgSO}_{4}$ 


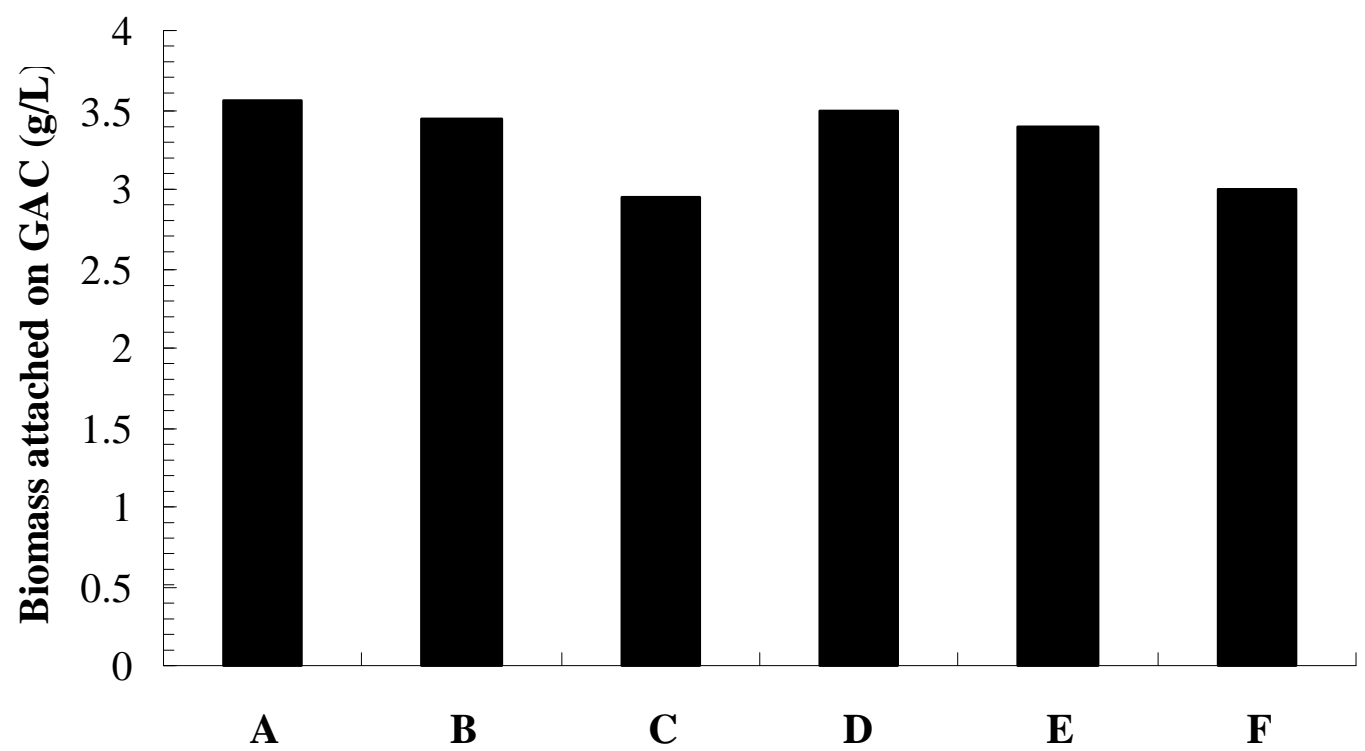

Figure 6. Biomass attached on $\mathrm{GAC}$ with different combinations of flocculants on $15^{\text {th }}$ day ( $\mathrm{SBCF}$ of $22 \mathrm{mg} / \mathrm{L}$ and $\mathrm{CaCl}_{2}$ of $2 \mathrm{mg} / \mathrm{L}$ for all conditions; $\mathrm{MgSO}_{4}$ of $5 \mathrm{mg} / \mathrm{L}$ for A, B, C and $10 \mathrm{mg} / \mathrm{L}$ for D, E, F; $\mathrm{FeCl}_{3}$ of $0.5 \mathrm{mg} / \mathrm{L}$ for A, D; $1 \mathrm{mg} / \mathrm{L}$ for B, E; 2 $\mathrm{mg} / \mathrm{L}$ for $\mathrm{C}, \mathrm{F}$ ) 


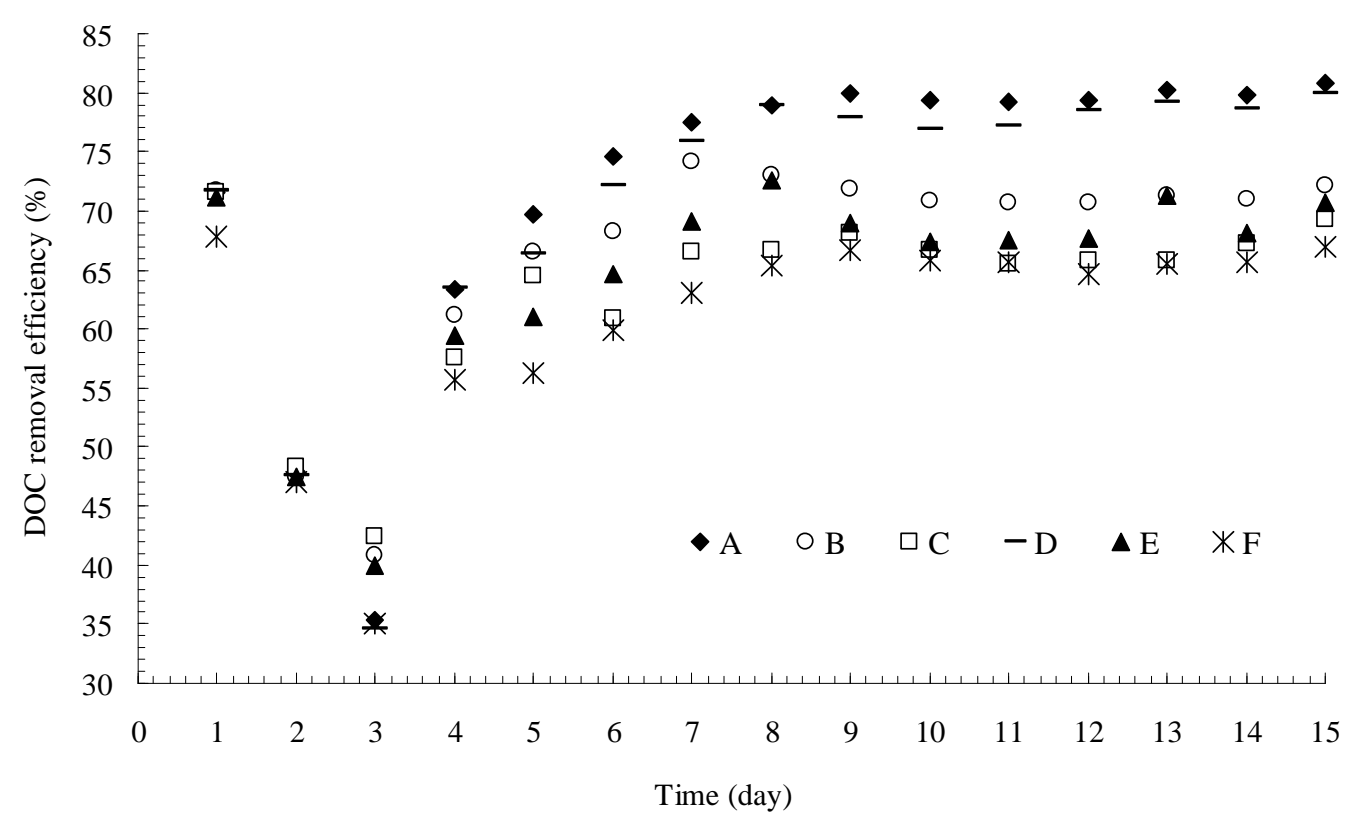

Figure 7. DOC removal efficiency of the different combined flocculants (initial DOC $=120 \mathrm{mg} / \mathrm{L} ; \mathrm{SBCF}$ of $22 \mathrm{mg} / \mathrm{L}$ and $\mathrm{CaCl}_{2}$ of $2 \mathrm{mg} / \mathrm{L}$ for all conditions; $\mathrm{MgSO}_{4}$ of 5 $\mathrm{mg} / \mathrm{L}$ for $\mathrm{A}, \mathrm{B}, \mathrm{C}$ and $10 \mathrm{mg} / \mathrm{L}$ for $\mathrm{D}, \mathrm{E}, \mathrm{F} ; \mathrm{FeCl}_{3}$ of $0.5 \mathrm{mg} / \mathrm{L}$ for A, D; $1 \mathrm{mg} / \mathrm{L}$ for $\mathrm{B}$, E; $2 \mathrm{mg} / \mathrm{L}$ for $\mathrm{C}, \mathrm{F}$ ) 